Primljen / Received: 11.2.2013.

Ispravljen / Corrected: 12.5.2013.

Prihvaćen / Accepted: 28.6.2013.

Dostupno online / Available online: 10.9.2013.

\section{Evaluation of site response characteristics using microtremors}

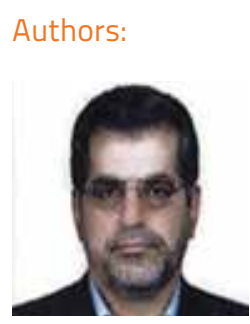

Prof. Asskar J. Choobbasti, PhD. CE Babol University of Technology Department of Civil Engineering Babol, Mazandaran, Iran asskar@nit.ac.ir

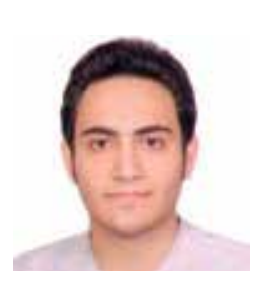

Sadegh Rezaei, MSc. CE

Babol University of Technology

Department of Civil Engineering

Babol, Mazandaran, Iran

S_Rezaei1366@yahoo.com

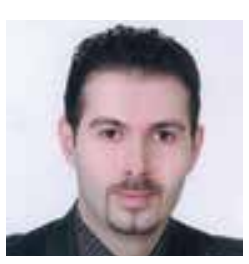

Assist.Prof. Farzad Farrokhzad, PhD. CE Mazandaran Institute of Technology Department of Civil Engineering

Babol, Mazandaran, Iran

FarzadFarokhzad@yahoo.com

\section{Asskar J. Choobbasti, Sadegh Rezaei, Farzad Farrokhzad}

\section{Evaluation of site response characteristics using microtremors}

In the two last decades the microtremor H/V spectral ratio method has been widely used for site effect studies. Straightforward estimate of the site effect of sediments and low-cost measurements are the main advantages of mentioned method. In this research the use of microtremor measurements in estimation of site response have been investigated. In order to assessing the accuracy of the measurements and its application in site effect evaluation, a preliminary site response modeling was carried out using the numerical methods. The results showed that the H/V spectral ratio approach provides an acceptable means of site effect evaluation in study area.

Key words:

Site effect, Microtremor, H/V spectral ratio, resonance frequency, amplification factor

Stručni rad

Asskar J. Choobbasti, Sadegh Rezaei, Farzad Farrokhzad

Procjena obilježja odziva tla mjerenjem mikropodrhtavanja

Omjeri spektra horizontalne i vertikalne komponente nemira kod mikropodrhtavanja posljednja se dva desetljeća često rabe pri istraživanjima uvjeta tla. Izravna procjena uvjeta sedimenata tla i mala cijena mjerenja osnovne su prednosti spomenute metode. U ovom članku analizira se metoda procjene odziva tla na osnovi mjerenja mikropodrhtavanja. Kako bi se procijenila točnost mjerenja i opravdanost njihove primjene pri procjeni uvjeta tla, preliminarno je modeliran odziv tla rabeći numeričke metode. Rezultati dokazuju da su omjeri spektra horizontalne i vertikalne komponente nemira kod podrhtavanja prihvatljiva metoda za procjenu uvjeta tla proučavanog područja.

Ključne riječi:

uvjeti tla, mikropodrhtavanja, H/V spektralni omjer, rezonantna frekvencija, faktor amplifikacije

Fachbericht

Asskar J. Choobbasti, Sadegh Rezaei, Farzad Farrokhzad

\section{Ermittlung von Eigenschaften der Bodenantwort mittels Mikrobeben}

In den letzten zwei Jahrzehnten ist das auf dem H/V Spektralverhältnis von Mikrobeben beruhende Verfahren weitreichend für Studien von Standorteinflüssen angewandt worden. Eine anschauliche Einschätzung der Standorteinflüsse von Sedimenten und kostengünstige Messungen sind die wesentlichen Vorteile dieser Methode. In dieser Arbeit ist die Anwendung der Messungen von Mikrobeben für die Bewertung der Bodenantwort untersucht worden. Anhand vorläufiger Modellierung der Bodenantwort mittels numerischer Methoden ist die Genauigkeit der Messungen für die Bestimmung von Standorteinflüssen erforscht worden. Die Resultate haben gezeigt, dass die auf dem H/V Spektralverhältnis beruhende Vorgehensweise für das gegebene Gebiet geeignet ist. 


\section{Introduction}

When an earthquake occurs, seismic waves radiate away from source and travel rapidly through the earth crust. When these waves reach the ground surface, they produce shaking that may last from several seconds to a few minutes [1]. During earthquakes, different alluviums with different structures show various reactions. Besides, the structure of the same alluvium may also show different response in different earthquakes. It is well-accepted that, besides the earthquake magnitude and fault distance, local geologic conditions, known as site effects, can also exert significant influences on the earthquake ground motion at a given location. Various methods are available for the estimation of site response. They are divided into two general groups: a) theoretical and numerical methods and b) field methods.

Theoretical and numerical methods study site effects by using mathematical equations which frequently require borehole data and dynamical specification of sites. In the field method, observations related to the earthquake specifications, explosion records and microtremor measurement records are studied.

The best method is to record the strong ground motion caused by a large local earthquake. However, such events are not frequent in Babol. Hence, this method was not proven to be practical for the site response analysis in this area. Other methods that can be used for the determination of soil properties in the study area are: extensive seismic reflection surveys, refraction surveys, spectral analysis of surface waves (SASW), multichannel analysis of surface waves (MASW), continuous generation of surface waves (CSWS), down-hole, up-hole, crosshole surveys, and geotechnical investigations. It should be added that this type of field work can not help us to evaluate the site response directly, but serves as an input for theoretical and numerical methods. However, these methods are extremely expensive and time consuming. Microtremor measurements are one of the internationally most popular methods for site response estimation especially in urban areas [2]. Microtremor measurements provide a relatively inexpensive and simple tool for obtaining two of the key parameters in site response studies, the site frequency and amplification factor $[3,4,5]$.

The city of Babol is one of the largest cities in the north of Iran (Mazandaran province). It lies on alluvium beds in the region presenting a high seismic potential. Therefore, comprehensive studies are necessary to introduce suitable solutions for minimizing earthquake damage and loss of life. In the present study, the Nakamura method (H/V spectral ratio) is used to evaluate the resonance frequency and amplification factor of ground vibrations in the study area. In addition, a preliminary site response modeling has been conducted using the 1-D site response program called SHAKE. Site frequencies obtained by modeling are presented and compared with site frequencies obtained through microtremor measurements. The objective of the present study is to evaluate the applicability of microtremors in the study area. For this purpose, the authors have used 15 microtremor recording stations and geotechnical data from six excavated boreholes.

\section{Site effects}

The evaluation of site effects due to local geology or topography has become a standard requirement in microzonation studies or site evaluation for important facilities [6]. The influence of local geologic and geotechnical soil conditions on the intensity of ground shaking, earthquake damage, and general characteristics of seismic waves such as the amplitude, frequency content and duration of strong ground motion, has been known for many years [1]. In particular, waves of certain frequencies can be amplified considerably by thick section of unconsolidated near-surface deposits [7]. Local amplification of ground is often controlled by the soft surface layer which leads to the seismic energy trapping, due to the impedance contrast between the soft surface soils and the underlying bedrock [8]. Over the past decades, the effect of local soil conditions is known to have caused serious damage during several earthquakes. Some well-known examples include the earthquake in Michoacan, Mexico in 1985, Kalamata, Greece 1989, Lomaprieta, California, USA 1989, Roodbar-Manjil, Iran 1990, Kocaeli and Duzce Turkey 1999 [9], Chi-Chi, Taiwan 1999, Bam, Iran 2003, and Wenchuan, China, 2008.

The soil can greatly amplify the earthquake shaking action. Thus a soft, loose soil may shake more intensely than hard rock at the same distance from the same earthquake. The amplification of ground motion due to local site conditions (such as topographical conditions and ground motion resonance, etc. Figure 1) plays an important role in the increase of seismic damage [1]. The seismic ground motion at any site is influenced by the type of soil in that region. Younger and softer soils usually amplify ground motion more than older soil or bedrock [8].

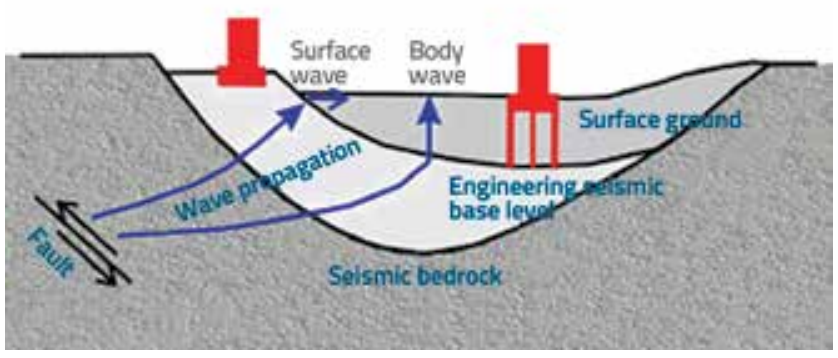

Figure 1. Depth section indicating soft soil layers at a location susceptible to site amplification

\section{Seismicity of Babol}

Unfortunately, Iran's human settlements and material infrastructure have been developing in disaster-prone areas such as the Babol city. Population in these communities has been steadily increasing and so an accurate natural hazard 
Table 1. List of historic and instrumentally recorded damaging earthquakes in and around Babol

\begin{tabular}{|c|c|c|c|c|}
\hline Location & Year & Source & Intensity & Magnitude \\
\hline Amol & 1809. & $20 \mathrm{~km}$ west from Babola & IX & 6,5 \\
\hline Talar rood & 1935. & $35 \mathrm{~km}$ southeast from Babola & VIII & 5,7 \\
\hline Chahar dange & 1935. & $60 \mathrm{~km}$ southeast from Babola & IX & 6,3 \\
\hline Band pey & 1957. & $10 \mathrm{~km}$ west from Babola & VI & 5,2 \\
\hline Babol & 1971. & Babol & VIII & 6,3 \\
\hline Kojoor & 2004. & $60 \mathrm{~km}$ northwest from Babola & VI & 5 \\
\hline Marzi kola & 2012. & Babol & \\
\hline
\end{tabular}

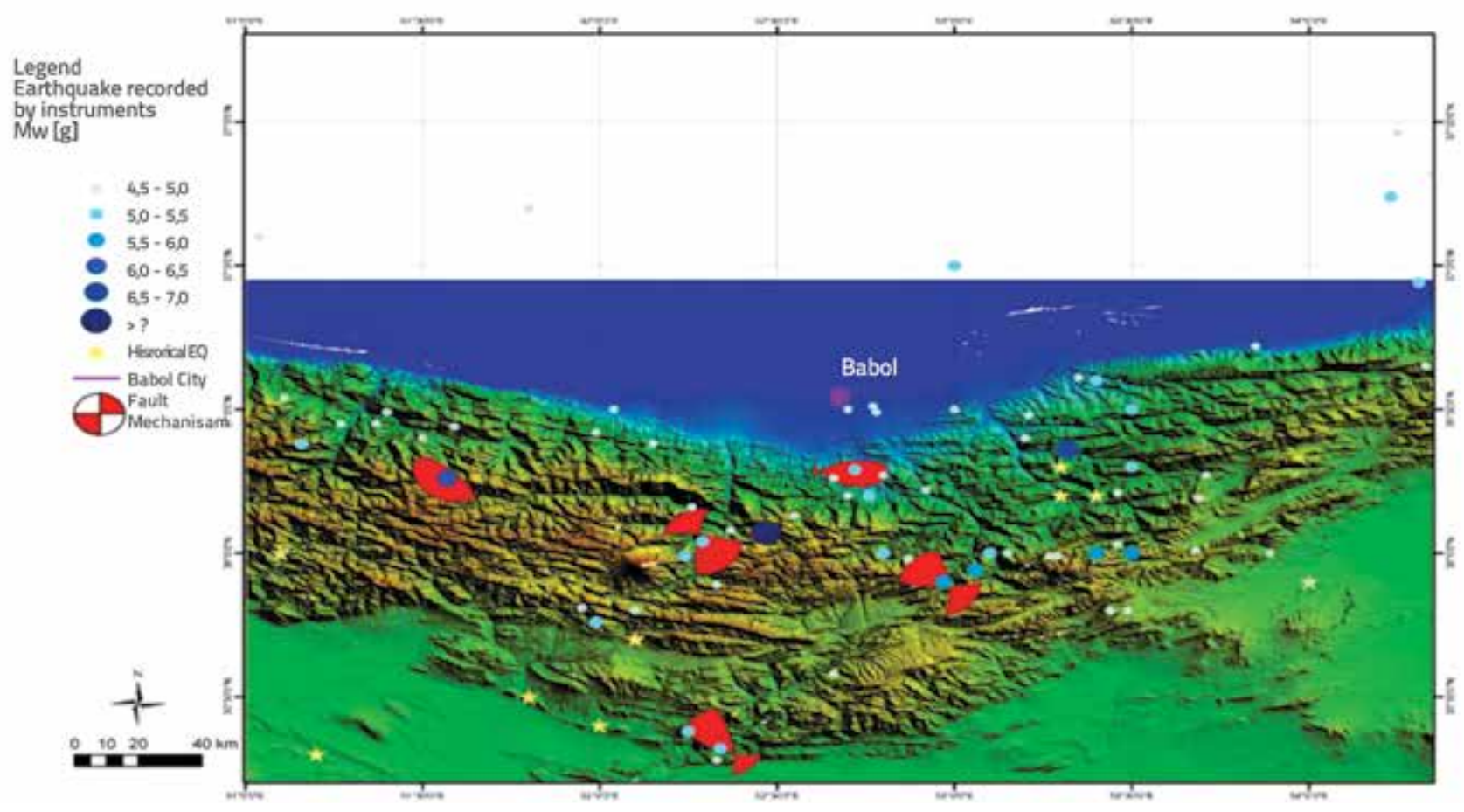

Figure 2. Location and magnitude of earthquakes, Faults and their mechanism near the Babol

risk assessment is necessary. Babol is located in front of Alborz Mountain which is a tectonically active region situated between the Caspian Sea and the Iran platform. The tectonics of Alborz Mountain is characterized by boundary conditions, due to convergent motion between Arabia and Eurasia, which probably started in the Cretaceous. The area around Babol has repeatedly experienced earthquakes. The locations, years of occurrence, magnitudes, and intensities of these earthquakes are reported in Table 1.

There are ample historical references showing that this area is prone to earthquake. The first historically reported major earthquake in this region, of intensity IX, occurred in 1809. The Amol earthquake resulted in severe loss of human life in Amol and Babol. It was felt in a very large area. The 1935Talarrood earthquake produced moderate shaking and was felt almost $190 \mathrm{~km}$ away. The 1935 Chahardange earthquake caused collapse of wooden houses in Sari, Babol, and Amol. The 1957 Bandpey earthquake produced violent shaking in Babol. Bandpey earthquake resulted in 1500 fatalities in Babol and caused severe damage in a number of places. The 1971 Babol earthquake produced moderate shaking and claimed one victim in Babol. The 2004 Kojoor earthquake claimed the lives of 35 persons in Mazandaran Province and, finally, the 2012 Marzi kola earthquake claimed one life in Babol. The location and magnitude of earthquakes and mechanism of faults in the Babol area is shown in Figure 2.

\section{Methodology}

The engineering application of microtremors was initially proposed by Kanai and Takana in 1961 [10]. The use of microtremors to study the resonant frequency of a site is a long-standing tradition in Japan [3, 10,11, 12]. It should be added that microtremors have also been used for site response evaluation in many other regions, including Mexico [6, 13], Spain [14], USA [4, 12, 15, 16], France [17], Portugal[18], and India [19, 20, 8].

As already indicated, microtremor measurements rank among the most popular techniques for estimating site 
effects in the regions with low seismicity [19, 3]. Based on literature review, the Nakamura method (H/V) has been used in several locations. Using this technique, the source effect can be minimized by normalizing the horizontal spectral amplitude with the vertical spectral amplitude [21]. The Nakamura technique has been described in several papers and is based on the following assumption about fundamental characteristics of microtremors:

a) Microtremors are composed of several waves, but essentially of Rayleigh waves propagating in a soft surface layer overlying a stiff substratum.

b) There are four Fourier spectral amplitudes involved: horizontal and vertical components of the motion at the surface and at the bottom of the layer $\left(\mathrm{V}_{\mathrm{S}^{\prime}} \mathrm{H}_{\mathrm{S}^{\prime}} \mathrm{V}_{\mathrm{B}^{\prime}} \mathrm{H}_{\mathrm{B}}\right)$, see Figure 3.

c) The effect of Rayleigh waves on the propagation of noise is included in the vertical spectrum at the surface $\left(\mathrm{V}_{\mathrm{S}}\right)$, but not at the base of the layer $\left(\mathrm{V}_{\mathrm{B}}\right)$.

d) The vertical component of the microtremor motion is not amplified by the soft layer.

e) The effect of Rayleigh waves on microtremor motion is equivalent for the vertical and horizontal components.

f) For a wide frequency range $(0.2-20 \mathrm{~Hz})$, the spectral ratio of the horizontal and vertical components of motion at the bottom of the layer is close to unity.

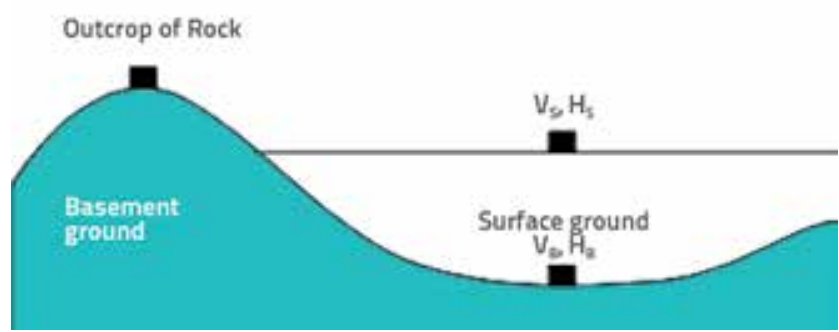

Figure 3. Illustration of a simple model assumed for the interpretation of microtremor H/V ratio as defined by Nakamura

It is usually assumed that transfer functions of surface layers can be given by the ratio

$$
S_{T}=H_{S} / H_{B}
$$

Where, $\mathrm{H}_{\mathrm{S}^{\prime}}$ is the horizontal component of the motion at the surface of the layer and $\mathrm{H}_{B}$, is the horizontal component of the motion at the bottom of the layer. However, considering the great contribution of Rayleigh Wave propagation to the ambient noise, it will be necessary to correct the ratio (1), in order to estimate the transfer function from microtremor measurements. Assuming that the vertical tremor is not amplified by surface layers, the ratio $\mathrm{E}_{\mathrm{RW}}$ defined below should represent the effect of the Rayleigh wave on the vertical motion (2):

$$
E_{R W}=V_{S} / V_{B}
$$

Assuming that the effect of the Rayleigh wave is equal for vertical and horizontal components, it is possible to define a corrected modified spectral ratio:

$S_{M}=S_{T} / E_{R W}=\left(H_{S} / H_{B}\right) /\left(V_{S} / V_{B}\right)$

As the final condition, it is assumed that for all frequencies of interest

$H_{B} / V_{B}=1$

Thus, an estimate of the transfer function is given by the spectral ratio between the horizontal and vertical components of the motion at the surface:

$S_{M}=H_{S} / V_{S}$

(In the following text, this ratio will be Indicated by H/V, without subscripts.) Many theoretical and experimental studies have shown that the spectral ratio obtained in this manner enables an adequate determination of the site fundamental frequency $[3,17,18,21]$.

\section{Data collection and analysis procedures}

In order to measure microtremors in the western part of Babol, the region under study was networked in the form of $700 \times 700$ $\mathrm{m}^{2}$ squares and one station was specified for measurement in each network. Figure 4 shows the network arrangement, and the location of microtremor recording stations and geotechnical boreholes. The microtremor recording stations are marked with white squares and the geotechnical boreholes with yellow arrows.

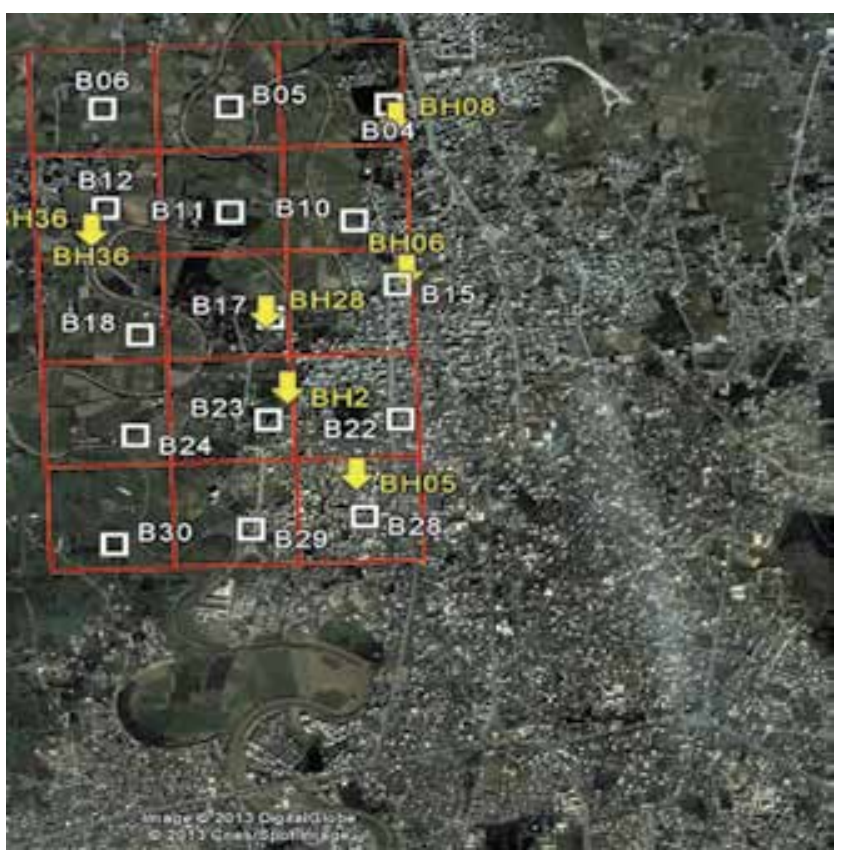

Figure 4. Location of microtremor recordings station and geotechnical boreholes 


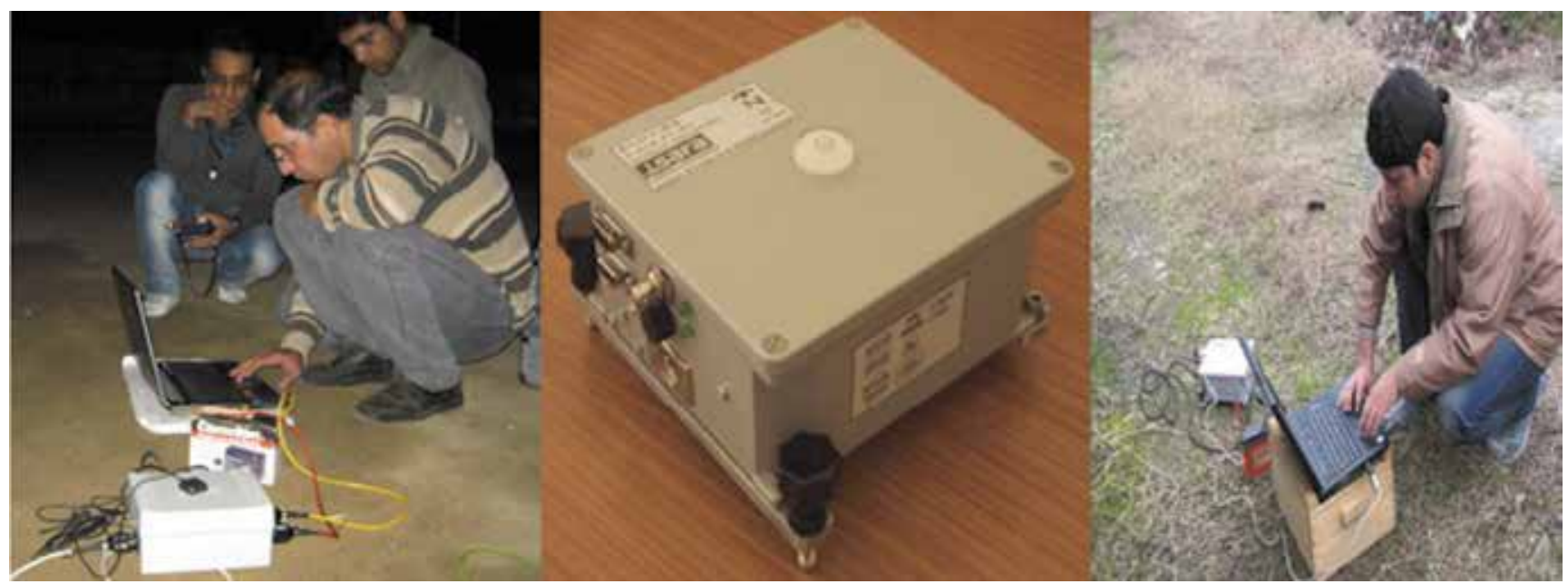

Figure 5. Microtremor observation and instrument set-up for microtremor measurements

The hardware used in the microtremor measurements consisted of velocity transducers with GPS, an amplifier, an analog-to-digital converter and a laptop for each data acquisition. Mucciarelli [21] suggests that seismometers should be used for microtremor data collection, and that the use of accelerometers should be avoided. His suggestions are based on the test he carried out using a Kinematrics FBA 23 accelerometer and Lennartz 3-D Lite and Mark L4C-3D seismometers. He has demonstrated that the results obtained by using an accelerometer varied significantly from those obtained by seismometers, especially in the low frequency $(<1 \mathrm{~Hz})$ range.

The velocity sensors had a natural period of 2 seconds. There sensors were deployed for every measurement, two in two orthogonal horizontal directions and one in vertical directions. The amplifier unit improved the quality of signals by extending the natural period to 5 seconds, filtering undesired frequencies, and amplifying the signal. A 3-channel, 24-bit analog-to-digital ( $A / D$ ) converter digitized the recorded data. The data acquisition laptop was used to monitor data collection, store the digitized data, and carry out preliminary on-site data analysis. (Figure 5)

Microtremor measurements were carried out in the study area in 2011 and 2012. The weather was generally calm with no strong winds or rain. Measurement locations were as close as possible to geotechnical borehole locations. Care was however taken to avoid direct heavy traffic pulses, manholes, foundations, or other underground structures. All experimental conditions for the current work were mostly defined by using precautions from the European SESAME research project $[23,24]$.

The use of ambient vibrations in the analysis of local site effects has been studied in detail in the framework of the European research project SESAME (Site Effects Assessment Using Ambient Excitations). The recommended guidelines on the H/V spectral ratio technique are the result of the comprehensive and detailed analyses performed by the SESAME participants during three years of investigations
(2001-2004). In this respect, the guidelines represent the state-of-the-art of the present knowledge on this method and its applications, and are based on the consensus reached by a large number of participants. It reflects the synthesis of a considerable amount of data collection and subsequent analysis and interpretations.

To reduce the effect of localized noise sources, such as industrial facilities, all records were taken between 10 p.m. and 3 a.m. In this experiment, the recording system was operated continuously for about 15 minutes. The recorder includes a GPS system so that the geographic position of each measurement point is known (Figure 5).

The processing starts by transforming the data from the Binary format to ASCII. The processing was carried out by the Geopsy and J-SESAME software. For each station, the time-series of the record is divided into windows of 25 (Sec) in duration (i.e., 2500 samples per window). Each window is base-line corrected for anomalous trends, tapered with a Hanning window and band-pass filtered from $0.2 \mathrm{~Hz}$ to $20 \mathrm{~Hz}$ [25]. The Fourier amplitude spectra of each selected window are computed and smoothed, and then two horizontal components are merged by applying the geometric mean [20]. The H/V spectral ratio of Nakamura [3] is applied for each individual window, and the final predominant frequency is obtained by averaging the H/V spectral ration as follows:

$$
H_{\text {avg }}(f) / V=\left(\sqrt{N^{2}(f)+E^{2}(f) / 2}\right) / V
$$

Where, N, E and $\mathrm{V}$ are the Fourier spectrum in N-S, E-W and up directions, respectively.

The first requirement, before any extraction of information and any interpretation, concerns the reliability of the H/V curve. Reliability implies stability, i.e., the fact that the actual H/V curve obtained with the selected recordings be representative of $\mathrm{H} / \mathrm{V}$ curves that could be obtained with other ambient vibration recordings, and/or with other physically reasonable window selection. 
Moreover, stability of the peak in the H/V curve was checked through three tests conducted at every measuring point where the same frequency peaks were picked for each site at different times. Sensitivity tests were also carried out at selected time window lengths during data processing; the result revealed a low dependence on the window length and, therefore, a high stability was achieved. Such a requirement has several consequences:

a) In order for a peak to be significant, the SESAME group recommend checking that the following condition is fulfilled: $f_{0}>10 / I_{w}\left(I_{w}\right.$ - window length). This condition is proposed so that, at the frequency of interest, there be at least 10 significant cycles in each window

b) A large number of windows and cycles is needed: the SESAME group recommend that, when using the automatic window selection with default parameters, the total number of significant cycles: $n_{c}=I_{w} \cdot n_{w} \cdot f_{0}$ be larger than $200\left(n_{w}\right.$ - number of windows selected for an average H/V curve) (which means, for instance, for a peak at $1 \mathrm{~Hz}$, that there be at least 20 windows of $10 \mathrm{~s}$ each; or, for a peak at $0.5 \mathrm{~Hz}, 10$ windows of $40 \mathrm{~s}$ each) and

c) An acceptably low level of scattering between all windows is needed. Large standard deviation values often mean that ambient vibrations are strongly non-stationary and undergo some kind of perturbations, which may significantly affect the physical meaning of the H/V peak frequency. Therefore it is recommended that $\sigma_{A}(f)$ be lower than a factor of 2 (for $f_{0}<0,5 \mathrm{~Hz}$ ), or a factor of 3 (for $f_{0}<0,5$ $\mathrm{Hz})$, over a frequency range at least equal to $\left[0,5 f_{0}\right.$ and $2 f_{0}$ ]]. ( $\sigma_{A}(f)$ standard deviation of amplitude of $\mathrm{H} / \mathrm{V}$ ).

Therefore, in case a particular set of processing parameters does not lead to satisfactory results in terms of stability, the SESAME group recommend reprocessing the recordings with some other processing parameters. This may be impossible in some cases as conditions for fulfilling items a), b) and c) above often lead to opposite tuning for some parameters. The safest decision is then to go back to the site and perform new
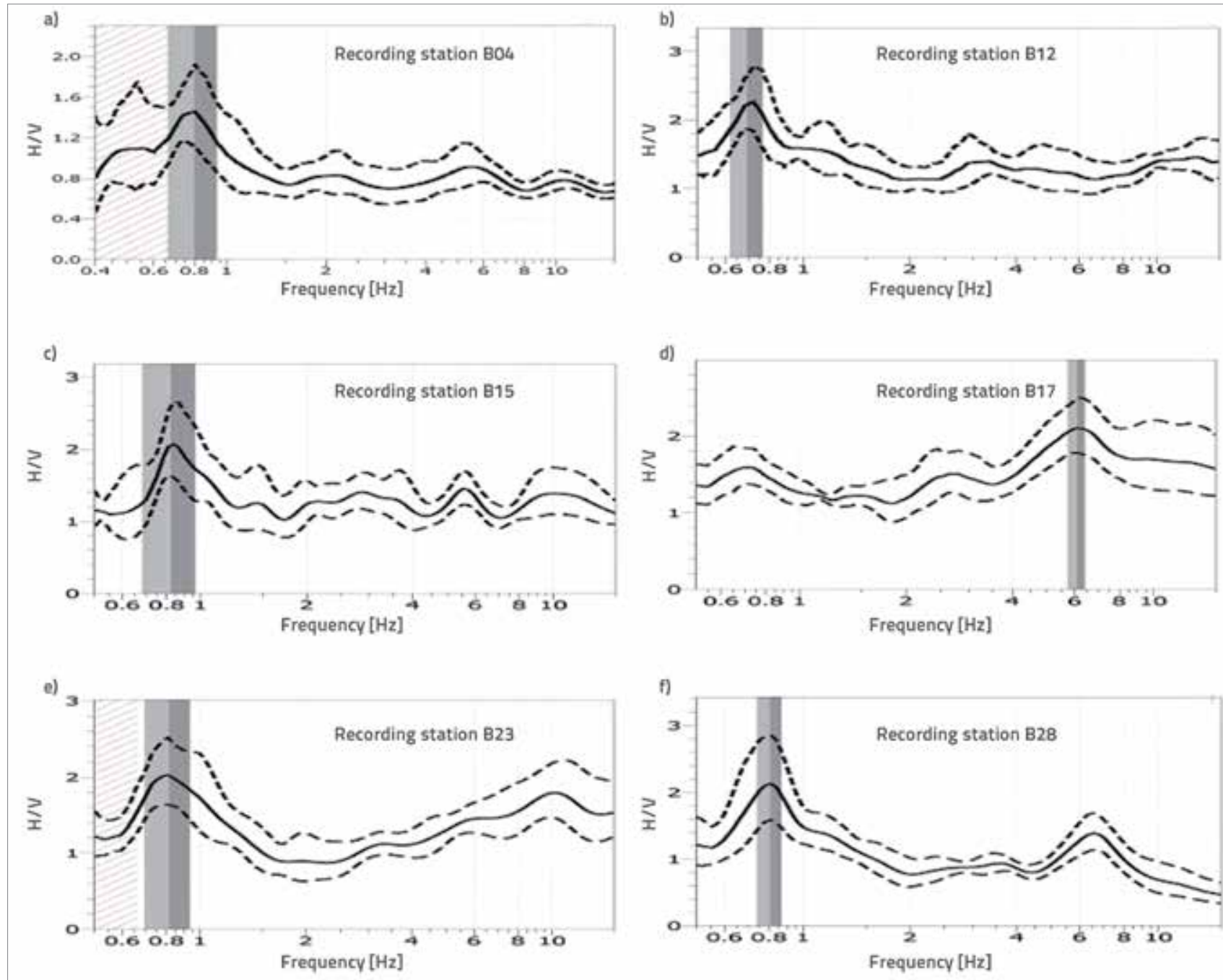

Figure 6. Plot of $H / V$ ratio with \pm 1 SD for microtremor recording stations 
Table 2. Results for all microtremor recording stations

\begin{tabular}{|c|c|c|c|c|c|}
\hline \multirow{2}{*}{ Station name } & \multirow{2}{*}{$A_{o}$} & \multirow{2}{*}{$f_{(\text {peak })}$} & \multicolumn{3}{|c|}{ Criteria for a reliable $\mathrm{H} / \mathrm{V}$ curves } \\
\hline & & & $f_{0}>10 I_{w}$ & $n_{c}>200$ & $\sigma f(0,5 f, 2 f)<2$ \\
\hline B04 & 1,4 & 0,86 & YES & YES & YES \\
\hline B05 & 2,2 & 0,92 & YES & YES & YES \\
\hline B06 & 2,7 & 0,92 & YES & YES & YES \\
\hline B10 & 2,1 & 1,32 & YES & YES & YES \\
\hline B11 & 3,2 & 6,80 & YES & YES & YES \\
\hline B12 & 2,1 & 0,67 & YES & YES & YES \\
\hline B15 & 2,1 & 0,83 & YES & YES & YES \\
\hline B17 & 2,1 & 6,10 & YES & YES & YES \\
\hline B18 & 3,0 & 8,10 & YES & YES & YES \\
\hline B22 & 1,7 & 0,76 & YES & YES & YES \\
\hline B23 & 2,0 & 0,80 & YES & YES & YES \\
\hline B24 & 3,5 & 0,86 & YES & YES & YES \\
\hline B28 & 2,1 & 0,80 & YES & YES & YES \\
\hline B29 & 1,7 & 7,00 & YES & YES & YES \\
\hline B30 & 2,9 & 6,70 & YES & YES & YES \\
\hline
\end{tabular}

measurements of longer duration and/or with more strictly controlled experimental conditions. In addition, one must be very cautious if the $\mathrm{H} / \mathrm{V}$ curve exhibits amplitude values that are very different from 1 (i.e., larger than 10, or lower than 0.1) over a large frequency range: in such a case, it is very likely that the measurements are invalid (for instance, malfunction in the sensor or the recording system, or very strong and close artificial ambient vibration sources), and should be redone. It is mandatory to check the original time domain recordings first $[24,2]$.

H/V spectral ratios for the selected windows have been computed at 15 surveyed sites. The H/V spectral ratio for stations B04, B12, B15, B17, B23 and B28 is shown in Figure 6 . These stations contain data from geotechnical boreholes. The analysis results for all recordings stations are shown in Table 2. In this table, $f_{\text {(peak) }}$ is the peak frequency and $A_{0}$ is the amplification factor. The last 3 columns are related to the confidence level of the results as recommended by European SESAME research project.

\section{Site modeling}

To validate the experimental technique, fundamental frequencies obtained through microtremor measurements were compared with 1-D numerical simulation results. In this respect, the SHAKE 2000 was used to compute response in the system of homogeneous viscoelastic layers of infinite horizontal extent, subjected to vertically traveling shear waves. The program is based on the continuous solution to wave equation [26] adapted for use with transient motions through the Fast Fourier Transform algorithm [27]. The nonlinearity of the shear modulus and damping is accounted for by the use of equivalent linear soil properties [28, 29] using an iterative procedure to obtain values for modulus and damping compatible with the effective strain in each layer [30].

Table 3. Mechanical properties of BHO6

\begin{tabular}{|c|c|c|c|c|}
\hline \multirow{2}{*}{$\begin{array}{c}\text { Borehole } \\
\text { name }\end{array}$} & $\begin{array}{c}\text { Depth } \\
{[\mathrm{m}]}\end{array}$ & $\begin{array}{c}\text { USCS } \\
\text { (Unified Soil } \\
\text { Classification } \\
\text { System) }\end{array}$ & $\begin{array}{c}\text { Unit weight } \\
{\left[\mathrm{g} / \mathrm{cm}^{3}\right]}\end{array}$ & $\begin{array}{c}\text { SPT } \\
\text { Number }\end{array}$ \\
\hline \multirow{4}{*}{ BH06 } & 3 & $\mathrm{CH}$ & 1,85 & 7 \\
\cline { 2 - 5 } & 7 & $\mathrm{CL}$ & 1,82 & 10 \\
\cline { 2 - 5 } & 11,6 & $\mathrm{ML}$ & 1,91 & 15 \\
\cline { 2 - 5 } & 14,7 & $\mathrm{CH}$ & 1,86 & 16 \\
\cline { 2 - 5 } & 29,3 & $\mathrm{CL}$ & 1,89 & 23 \\
\hline
\end{tabular}

Table 4. Peak frequencies and amplification factors calculated by SHAKE 2000

\begin{tabular}{|c|c|c|c|}
\hline $\begin{array}{c}\text { Borehole } \\
\text { name }\end{array}$ & $\begin{array}{c}\text { Microtremor station } \\
\text { located near borehole }\end{array}$ & $\boldsymbol{A}_{o}$ & $\boldsymbol{f}_{\text {(peak) }}$ \\
\hline BH08 & B04 & 1,13 & 0,74 \\
\hline BH36 & B12 & 1,97 & 0,58 \\
\hline BH06 & B15 & 1,65 & 0,65 \\
\hline BH28 & B17 & 2,30 & 3,80 \\
\hline BH02 & B23 & 1,85 & 0,67 \\
\hline BH05 & B28 & 1,75 & 0,85 \\
\hline
\end{tabular}


The use of geotechnical data for each site, and the synthesis of drilling data extracted from the Babol's subsurface database, enabled determination of soil columns representative of each site. The sample of boreholes data is shown in Table 3.

Using the soil configuration, the fundamental frequency and amplification factor were calculated for each site using the SHAKE 2000 numerical code. The results of this analysis for 6 boreholes are shown in Table 4.

\section{Results and discussion}

\subsection{Microtremor measurements results}

H/V spectral ratios for selected windows were computed at 15 surveyed sites (Figure 6.a-f). The presence of clear peak of the H/V curve (Figure 6.a-b-c-e) is considered to be indicative of the impedance contrast between the uppermost surface soil and the underlying hard rock, where large peak values are generally associated with sharp velocity contrasts, and is likely to amplify the ground motion [24]. Two peaks that reflect the presence of two large impedance contrasts are shown in Figure 6.f while a broad peak, or a plateau-like curve, is shown in Figure 6.d, which could be related to the presence of an underground sloping of the interface between softer and harder layers [24, 2].. According to the analysis, the peak frequency $f_{\text {(peak) }}$ varies from 0.67 to $8.10 \mathrm{~Hz}$ within the study area. The most part has lower values of $f_{\text {(peak) }}$ (less than $1 \mathrm{~Hz}$, about $60 \%$ ) (Figure 7). These low values point to a large thickness of sediments. However, there are some localized areas with higher values of $f_{\text {(peak) }}$ (up to $8.10 \mathrm{~Hz}$ ). Parolai et al. (2002) state that the resonance frequency becomes lower in areas where the basement depth is greater, and higher in zones where it is shallower.

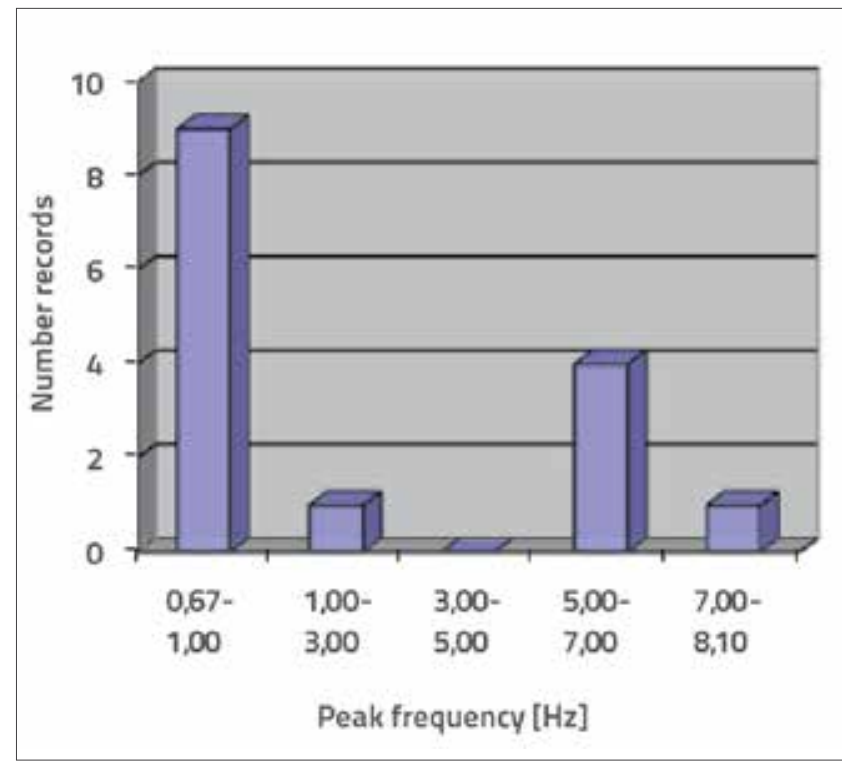

Figure 7. Relation between the number of records and their peak frequency values

\subsection{Comparison of microtremor measurements and site modeling data}

There appears to be some agreement that the H/V spectral ratio curves are independent from the source excitation function and strongly correlated to the local geological structure [32]. On this basis, it is possible to produce a theoretical H/V curve from a known (constrained) geological structure [33]. One dimensional simulation is an appropriate technique for the evaluation of site response due to local geology. At the study area, the information on the geotechnical

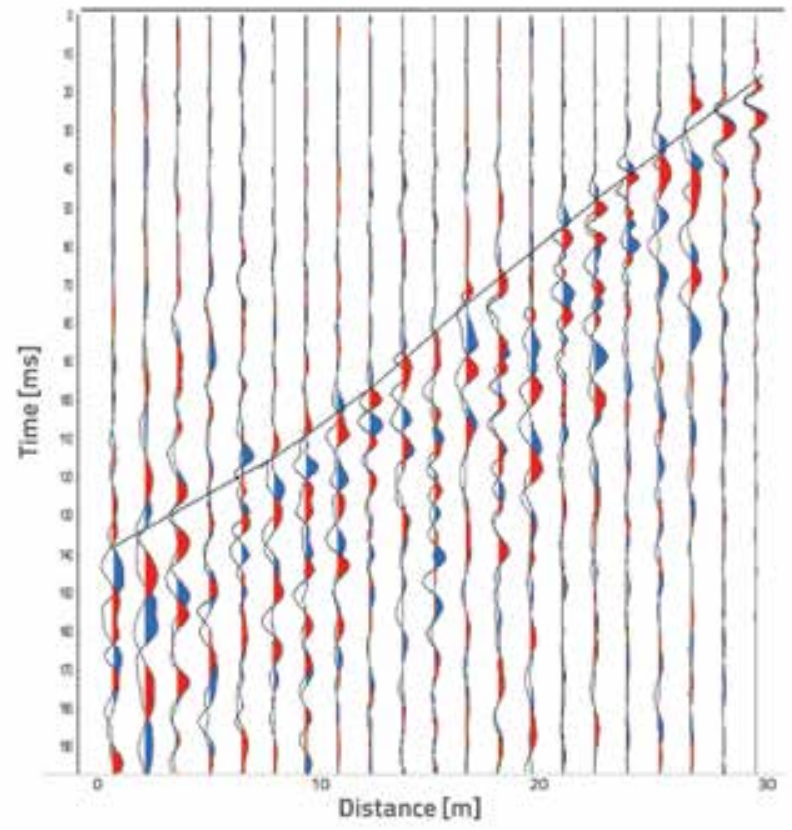

Figure 8. record of shear wave velocity in borehole BHO6

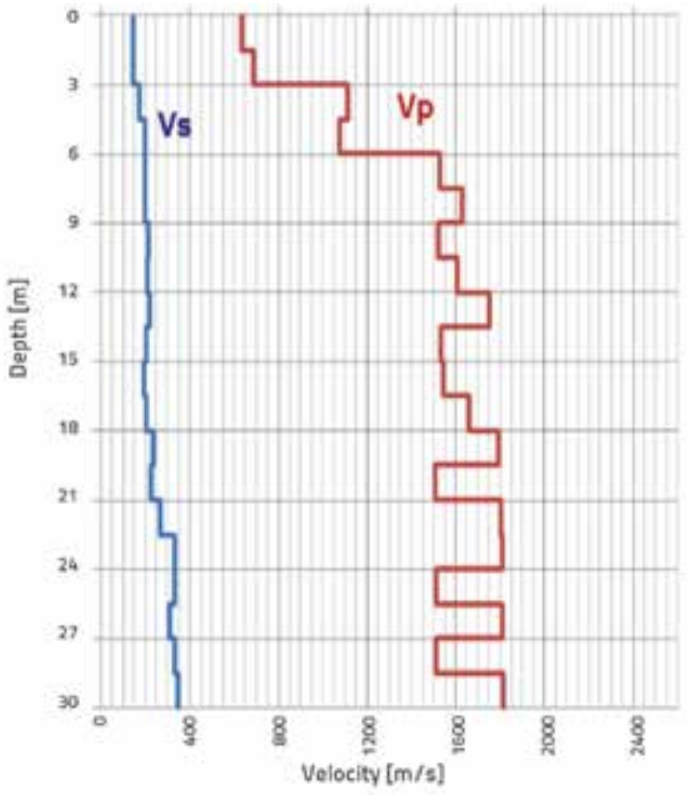

Figure 9. Shear wave velocity in borehole BHO6 
structure was obtained from 3 distinct sources: a) borehole data which reveal the thickness and type of soil, b) SPT data which were correlated to give the possible range of S-wave velocities and densities of layers, c) further confirmation of the S-wave velocity profiles through down-the-hole testing. The geological structure and the properties deduced from 3 independent sources were summarized and associated with equivalent S-wave values.

With respect to the above descriptions, a sample of shear wave records in borehole $\mathrm{BHO6}$ is presented in Figure 8, while the record analysis results (shear wave velocity in each depth) are shown in Figure 9. As can be seen from Table 5, the down-the-hole test results and the values introduced by Ishihara and Ansal [34] are in a same range, which confirms the accuracy of the down-the-hole test.

Table 5. Shear wave velocity values obtained by down-the-hole test in BHO6 and introduced by Ishihara and Ansal [34]

\begin{tabular}{|c|c|c|c|}
\hline \multirow{3}{*}{$\begin{array}{c}\text { Borehole } \\
\text { name }\end{array}$} & $\begin{array}{c}\text { Depth } \\
{[\mathrm{m}]}\end{array}$ & \multicolumn{2}{|c|}{$\mathrm{V}_{s}$ [m/s] } \\
\cline { 3 - 4 } & & Down-the-hole & $\begin{array}{c}\text { Ishihara \& Ansal, } \\
{[34]}\end{array}$ \\
\hline \multirow{4}{*}{ BH06 } & 3 & 169,8 & $<200$ \\
\cline { 2 - 4 } & 7 & 200,8 & $200-300$ \\
\cline { 2 - 4 } & 11,6 & 208,6 & $200-300$ \\
\cline { 2 - 4 } & 14,7 & 212,7 & $200-300$ \\
\cline { 2 - 4 } & 29,3 & 345,5 & $300-500$ \\
\hline
\end{tabular}

Peak frequency results obtained by the SHAKE software are presented in Table 4 and compared with the microtremor fundamental frequency in Figure 10. The amplification factor results obtained by SHAKE are presented in Table 4 and compared with the microtremor amplification factor in Figure 11.

Figures 10 and 11 reveal a good overall correspondence between peak frequencies obtained by the two methods, although the amplification obtained by the H/V ratio is generally higher than that obtained by numerical modeling. By comparing the peak frequency values it was observed that stations three, two and one show a very good, good and weak confidence, respectively. The reason for non-conformity of station B17 can be due to the fact that geotechnical structure of the mentioned borehole shows considerable changes in the slope of subsurface soil layers. In this case 3-D analysis would have been more appropriate.

A general assessment shows that in almost all stations, except for the station 28 , the frequency obtained from microtremor is somewhat higher than that obtained by numerical method. By comparing the amplification factor obtained by two methods, it is apparent that the amplification factor estimated through the microtremor method is higher than that obtained by numerical simulation, but the results are sufficiently compliant to one another at some recording stations. These results are in agreement with research presented by Bour et al. [17]. It can be concluded that non-linear effects generally lead to a diminution of ground acceleration amplification factors, and to a slight shift of the significant dominant frequency towards the lower frequencies. At low accelerations (PGA < $0.3 \mathrm{~g})$, the differences between the fundamental frequencies based on the linear or non-linear assumption are probably not significant.

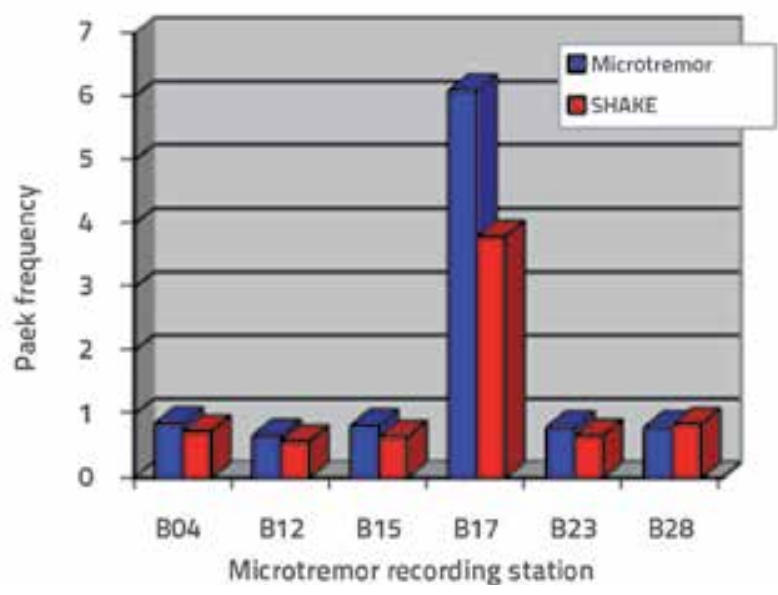

Figure 10. Comparison of site peak frequencies for the studied area

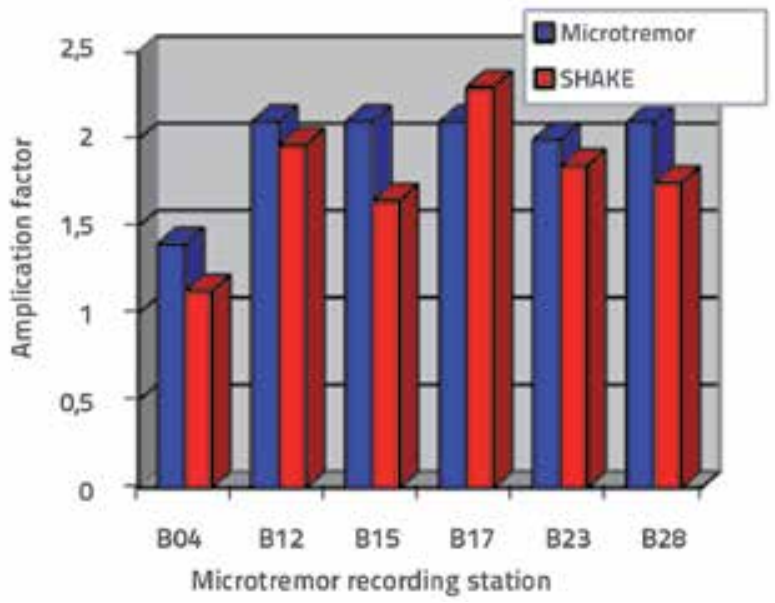

Figure 11. Comparison of site amplification factors for the studied area

\section{Maps of resonance frequency and amplification factor}

Each station enables estimation of the peak frequency and amplification. The interpolation between the microtremor stations was carried out in order to represent the spatial distribution of peak frequency values across the Babol basin. Peak frequency values for Babol Basin varying from $0.67 \mathrm{~Hz}$ to $8.10 \mathrm{~Hz}$ are shown in Figure 12. Most parts of the study area show lower peak frequency values ranging from $0.67 \mathrm{~Hz}$ to $0.92 \mathrm{~Hz}$. Higher peak frequency values were obtained in the central part. An increase of peak frequency values from west to center, and decrease of these values from center to east, 

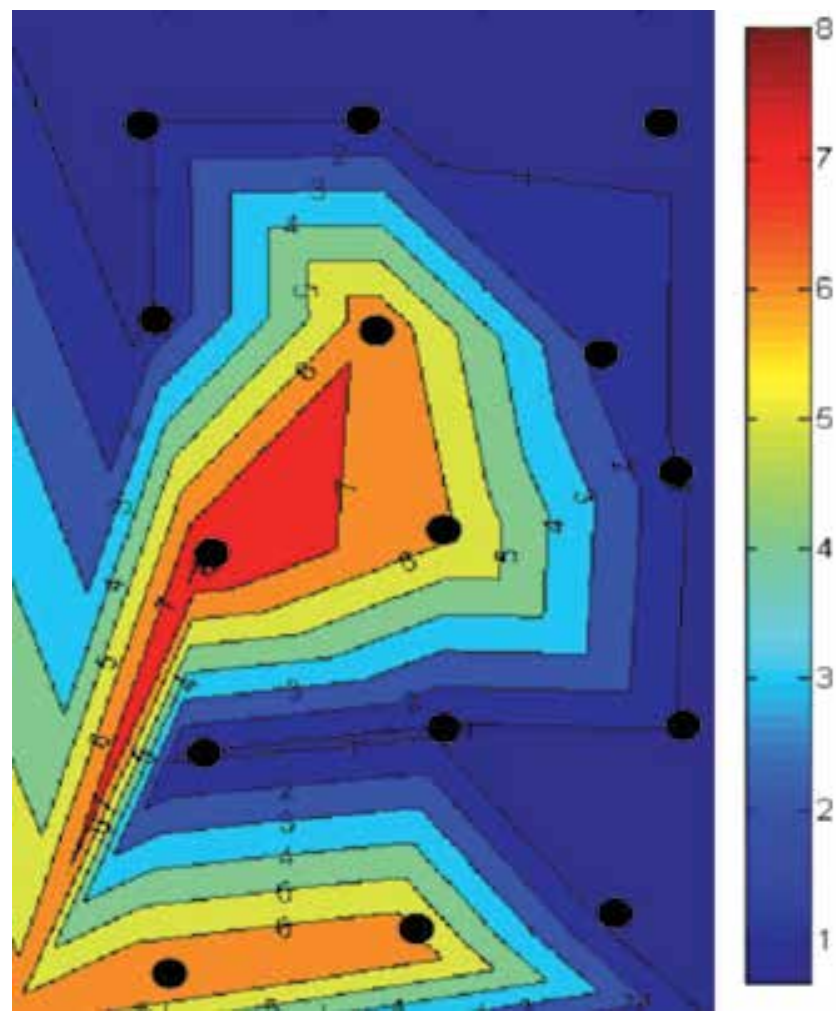

Figure 12. Map of peak frequency

show changes of alluvial deposits along these directions.

The amplification factor for Babol basin, varying from 1.4 to 3.5, is shown in Figure 13. A lower amplification factor varying from 1.4 to 2.2 is shown in the major part of the basin. The eastern part is characterized by lower amplification factor values. However, some localized areas, distributed across the central, western and southwestern parts of the study area, present higher amplification factor values (up to 3.5).

\section{Conclusions}

The city of Babol is built on thick soft sediments, which could reasonably amplify the earthquake ground motion in case of a seismic event. As no site effect analyses have been carried out in the city, it is believed that a detailed study of the local response of Babol should be of some concern in terms of seismic hazard. The site frequency and amplification investigation at nodes on a $700-\mathrm{m}$ grid, within the $3.5-\mathrm{Km}$ by $2.1-\mathrm{Km}$ area in Babol, is presented in this paper. The data set obtained shows that fundamental frequency values vary within short distance intervals in Babol. A series of microtremor measurements in the study area resulted in site

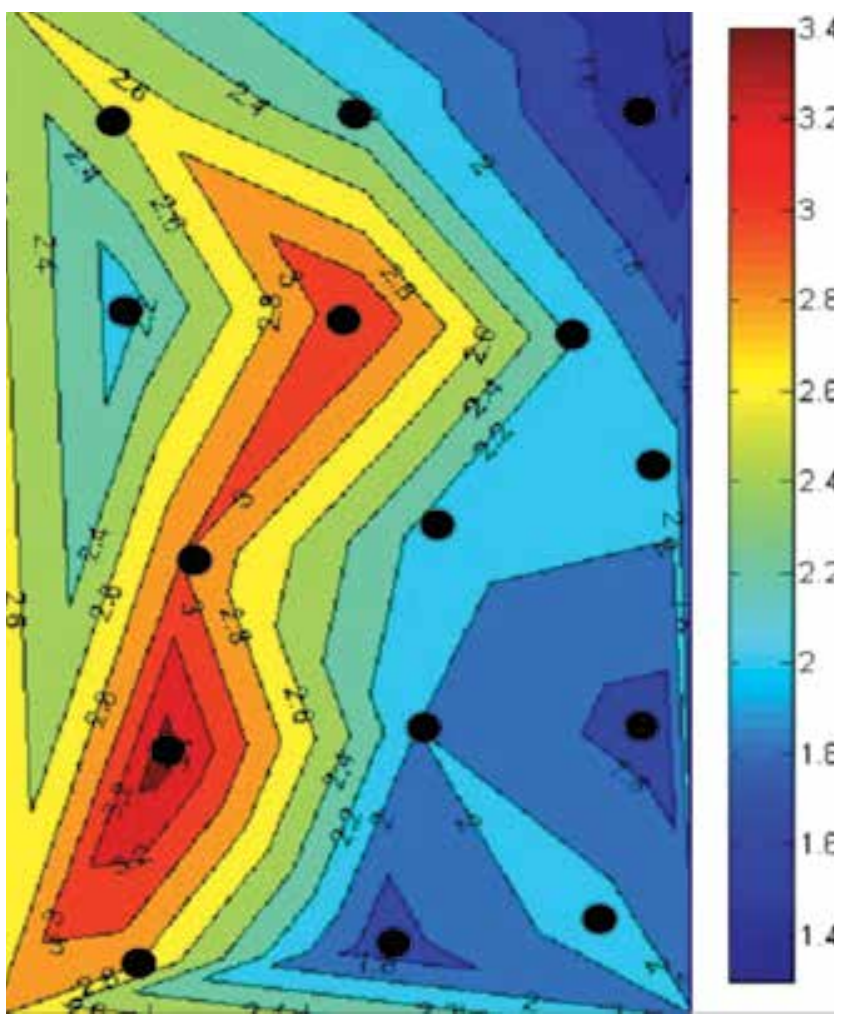

Figure 13. Map of amplifications at peak frequency

frequency values ranging from 0.67 to $8.10 \mathrm{~Hz}$. The central part of the studied area is characterized by higher peak frequency values. An increase of peak frequency values from west to center, and decrease of such values from center to east, point to changes of the alluvial deposits along these directions. The data analysis has shown that the amplification factor for Babol basin varies from 1.4 to 3.5. A lower amplification factor ranging from 1.4 to 2.2 was obtained in a major portion of the basin. Site frequencies were also estimated by preliminary 1-D site modeling using the SHAKE program. The highest site frequency obtained by SHAKE modeling was $3.80 \mathrm{~Hz}$, for which microtremor measurement indicated the site frequency of $6.10 \mathrm{~Hz}$. In general, a reasonable correspondence between the methods was obtained, although in few cases the frequency computed by SHAKE differed from the measured microtremor frequency. This difference could be due to the use of the 1-D analysis instead of the 3-D analysis in the zone presenting high slope in the subsurface soil layers. As a final conclusion, it can be indicated that, according to these results and in spite of some fluctuations in the amplitude, the use of microtremor measurements seems to be very useful for estimating the site response, in terms of fundamental frequency. 


\section{REFERENCES}

[1] Kramer, S.: Geotechnical Earthquake Engineering. Prentice Hall, 1996.

[2] Fnais, M.S., Abdelrahman, K., Al-Amri, A.M.: Microtremor measurements in Yanbu city of Western Saudi Arabia: A tool for seismic microzonation. Journal of King Saud University, 22, 97110, 2010.

[3] Nakamura, Y.: A method for dynamic characteristics estimation of subsurface using microtremor on the ground surface, Quarterly Report of RTRI, 30, 25-33, 1989.

[4] Field, E. H., Jacob, K. H.: The Theoretical response of sedimentary layers to ambient seismic noise. Geophysic Research Letters, 20-24, 2925-2928, 1993.

[5] Bard, P. Y.: Lecture Notes on Seismology, Seismic Hazard Assessment and Risk Mitigation. International Training Course, Potsdam, 160, 2000.

[6] Lermo, J., Chavez-Garcia, F. J.: Site effect evaluation using spectral ratio with only one station. Bulletin of Seismological Society of America, 83. 1574-1594, 1993.

[7] Borcherdt, R. D., Gibbs, J. F.: Effects of local geological conditions in the San Francisco bay region on ground motions and the intensities of the 1906 earthquake. Bulletin of Seismological Society of America, 66, 467-500, 1976.

[8] Purnachandra Rao, N., Ravi Kumar, M., Seshunarayana, T., Shukla, A.K., Suresh, G., Pandey, Y., Dharma Raju, R., Pimprikar, S. D., Chandra Das, Kalpna Gahalaut, Mishra, P. S., Harsh Gupta.: Site amplification studies towards seismic microzonation in Jabalpur urban area, central India. Physics and Chemistry of the Earth,36, 1247-1258, 2011.

[9] ilerisoy, Z.Y., Soyluk, A.: Impact of Shallow Earthquakes on the Sehzade Mehmet Mosque, GRADEVINAR 64 (2012) 9, 735-740.

[10] Kanai, K., Takana, T.: On microtremors. VIII. Bulletin Earthquake Research institute, 39, 97-114.

[11] Kanai, K., Osada, K., Yoshizawa, S.: Observational study of earthquake motion in the depth of the ground. Bulletin earthquake research Institute Tokyo, 32, 361-370, 1954.

[12] Akamatsu, J.: Seismic amplification by soil deposits inferred from vibrational characteristics of microseisms. Bulletin Disaster prevent research institute Kyoto university, 34, 105-127, 1984.

[13] Kobayashi, H., Seo, K., Midorikawa, S.: Estimated strong ground motions in the Mexico city due to Michoacan, Mexico earthquake of September 19, 1985 Based on the Characteristics of microtremor. The graduate school of Nagatsuta, Tokyo Institute of Technology, 34-68, 1986.

[14] Morales, J., Ibanez, J., Vidal, F., De Miguel, F., Alguacil, G., Posadas, A.: Qc Site dependence in the Granada Basin (Southern Spain). Bulletin Seismological Society Of America, 80, 278-285, 1991.

[15] Seo, K., Samano, T., Yamanaka, H., Hao, X., Koyama, S., Takeuchi, M., Fujioka, K., Kishino, Y., Kawano, K., Asano, K., Nakajima, N., Murai, M., Mualchin, L., Hisada, Y.: Microtremor measurements in the San Francisco bay area, 4th International Conference On Seismic Zonation, 3, 417-424, 1991.

[16] Dravinski, M., Yamanaka, H., Nakajima, Y., Kagami, H., Keshavamurthy, R., Masaki, K.: Observation of long period microtremors in San Francisco metropolitan area. 4th International Conference On Seismic Zonation, 3, 401-407, 1991.

[17] Bour, M., Fouissac, D., Dominique, P., Martin, C.: On the use of microtremor rcordings in seismic microzonation, soil dynamic and eartquake engineering, 17, 465-474, 1998.
[18] Teves-Costa, P., Matias, L., Bard, P. Y.: Seismic behavior estimation of thin alluvium layers using microtremor recordings. Soil Dynamic and Earthquake Engineering, 15, 201-209, 1996.

[19] Mukhopadhyay, S., Bormann, P.: Low cost seismic microzonation using microtremor data: an example from Delhi, India. Journal of Asian Earth Sciences, 24. 271-280, 2004.

[20] Yanger Walling, M., Mohanty, W.K., Nath, S.K., Mitra, S., John, A.: Microtremor survey in Talchir, India to ascertain its basin characteristics in terms of predominant frequency by Nakmaura's ratio technique, Engineering Geology, 106, 123-132, 2009.

[21] Tuladhar, R.: Seismic Microzonation of the Greater Bangkok with Microtremor Observations, thesis for degree of Master of Engineering, Asian Institute of Technology, School of Civil Engineering, 2002.

[22] Mucciarelli, M.: Reliability and applicability of Nakamura's technique using microtremors: an experimental approach. Journal of Earthquake Engineering, 2, 625-638, 1998.

[23] SESAME: Site Effects using Ambient Excitations. http:// sesame-fp5.obs.ujf-grenoble.fr, 2003.

[24] SESAME Project: Site Effects using Ambient excitations. http:// sesame-fp5.obs.ujf-grenoble.fr, 2004.

[25] Castro, R. R., Anderson, J. G., Singh, S. K.: Site response, attenuation and source spectra of $\mathrm{S}$ waves along the Gurrero, Mexico, subduction zone. Bulletin of Seismological Society of America, 80, 1481-1503, 1990.

[26] Kanai, K.: Relation between the nature of surface layer and the amplitude of earthquake motions, Bulletin Tokyo Earthquake Research Institute, 1951.

[27] Cooley, J.W., Tukey, J.W.: An algorithm for the machine calculation of complex Fourier series. Math Computer, 19, 297-301, 1965.

[28] Idriss, I. M., Seed, H. B.: Seismic Response of Horizontal Soil Layers. Journal of soil mechanics and foundations division, 54, 83-118, 1968.

[29] Seed, H. B., Idriss, I. M.: Soil moduli and damping factors for dynamic response analysis. Report No. EERc 70-10, University of California, Berkeley, December, 1970.

[30] Ordonez, G.L.: A computer program for 1-D analysis of geotechnical earthquake engineering problems, University of California, Berkeley, 2011.

[31] Parolai, S., Bormann, P., \& Milkereit, C.: New relationships between Vs thickness of sediments, and resonance frequency calculated by H/V ratio of seismic noise for the Cologne area (Germany). Bulletin of Seismological Society of America, 92. 2521-2526, 2002

[32] Lachet, C., Hatzfeld, D., Bard, P.Y., Theodulidis, N., Papaioannou, C., \& Savvaidis, A.: Site effect and microzonation in the city of Thessaloniki (Greece). Comparison of different approaches, Bulletin of Seismological Society of America, 86. 1692-1703, 1996.

[33] Harutoonian, P., Chapman, B., Leo, C. J., Liyanapathirana, S.: Characterisation of an urban site by ambient noise HVSR method: resonance frequencies and site amplifications. GeoFlorida 2010: Advances in Analysis, Modeling \& Design, 199, 1152-1161, 2010

[34] Ishihara, K., Ansal, A. M.: Dynamic behavior of soils, amplification and soil-structure interaction. Final report for working group D., UNDP/UNESCO project on earthquake reduction in the Balkan region, 1982. 